\title{
The Effect of Managerial Supervision and Work Motivation on Improving Principal's Performance
}

\author{
Susmadiana \\ Dinas Pendidikan Propinsi Sumatera Selatan \\ e-mail: susmadianasomad@gmail.com \\ Bukman Lian \\ Universitas PGRI Palembang \\ e-mail: drbukmanlian@univpgri-palembang.ac.id \\ Yenny Puspita \\ Universitas PGRI Palembang \\ e-mail: yennypuspita@ univpgri-palembang.ac.id \\ Article History: Received on 9 November 2021, Revised on 4 December 2021 \\ Published on 14 December 2021
}

\begin{abstract}
This study focuses on the problem of the Effect of Managerial Supervision and Work Motivation on the Performance Improvement of the Principal of SMA Ogan Komering Ulu Regency. This research used questionnaire and documentation, and it is concluded that managerial supervision has a significant positive effect on employee performance. Managerial supervision has a value that is greater than the coefficient of work motivation variable. This indicates that the influence of managerial supervision variables tends to be greater in influencing employee performance than the work motivation variable, and the work motivation variable also has a positive influence on employee performance. The results of the simple regression analysis show that the t-test results are also statistically significant. It can be seen that there is a significant effect of managerial supervision and employee motivation on employee performance variables. The significant effect of this hypothesis can be seen through the F test. If F-count is greater than F-table, the independent variables have a significant effect on the dependent variable.
\end{abstract}

Keywords: Managerial Supervision, Motivation, Performance

\section{A. Introduction}

The main issue in efforts to improve educational quality is the development of education in all aspects. The effectiveness of the principal's implementation of the principal duties and functions in an effort to improve the quality of education in his place of duty is one of the issues of improving education quality. This is related to the principal's leadership and effective management. Support from teachers, staff, and other school residents will exist and be sustainable if the leaders are truly qualified. Leadership is essential in pursuing and improving educational quality, because improving educational quality is a shared desire of all schools. The principal is a teacher who has the ability to lead all existing resources in a school so that they can be used optimally to achieve common goals (Firman et. al, 2021). The principal is the school's highest-ranking official. The style of leadership he employs will have a significant impact on the success of the school he leads (Susilawati et. al, 2021). 
Volume 2 (2) 2021

E-ISSN: 2723-6919 P-ISSN: 2746-0827

In the context of modern education, the principal's leadership includes strategic positions in achieving legally mandated educational goals. The principal has specific and systematic main tasks and functions to carry out in his role as a leader in the education unit. According to the Minister of National Education's attachment No. 19 of 2007, dated May 23, 2007, concerning Standards for Management of Education by Primary and Secondary Education Units, it includes (1) program planning, (2) work plan implementation, (3) supervision and evaluation, (4) school leadership, and (5) school information system. According to the attachment to Permendiknas Number 13 of 2007, dated April 17, 2007, page 5, regarding the standards of principals/Madrasahs, a school principal must meet five dimensions of competence, namely personality, managerial, entrepreneurial, supervisory, and social. Each dimension of competence has fundamental competencies that the Principal must possess.

Improving the quality of principals is essentially an activity focused on intelligence, skills, abilities, and inner and outer health. The ability of the principal who manages education has a strong influence on the high and low quality of education in schools. The low level of ability of the principal will have an effect on the level of education. A school principal's role is required to improve educational quality through student learning outcomes, teacher and educational staff accomplishments, and the fulfillment of 8 (eight) national education standards.

Improving the quality of school principals requires good guidance and supervision from school administrators. The work program of school supervisors and principals is an integral part of school organizations, where schools can run smoothly and well if carried out through joint coordination according to their respective main functions. In the context of increasing school principals' competence in accordance with Government Regulation No. 19 of 2005, Article 1 concerning National Education Standards is the minimum criterion for the education system in all jurisdictions of the Unitary State of the Republic of Indonesia.

Article 1 of RB Regulation No. 21 of 2010 governing the functional position of the School Supervisor is a functional position with the scope of duties, responsibilities, and power to carry out academic and managerial supervisory activities in the education unit. As a result, training supervisors to be capable of carrying both academic and management supervisory tasks is critical. Permendiknas No. 12 of 2007 on Standards for School/Madrasah Supervisors emphasizes that a supervisor must have 6 (six) minimum competencies, namely personality competence, managerial supervision, academic supervision, educational evaluation, research and development, and social competence.

Managerial supervision is an effort made by a supervisor to enhance work patterns and school performance, including principal performance, in order to have a beneficial influence on teaching and learning processes and outcomes, as well as educational quality. The primary function of educational supervision is to improve the quality of learning through developing schools in general and instructors in particular (Devi et al, 2021).

The supervisor's role in the school environment is highly crucial, because teachers, as the spearhead of education, require consultation and discussion about the teaching and learning process that is their area in order to enhance teacher performance. According to a survey of supervisors in a district conducted by the Directorate of Education Personnel in 2008 (Directorate General of Quality Improvement for Educators and Education Personnel, 2009), supervisors have weaknesses in academic supervision, managerial supervision, educational evaluation, and research and development. This situation is similar to that of Ogan Komering 
Volume 2 (2) 2021

E-ISSN: 2723-6919 P-ISSN: 2746-0827

Ulu Regency at the moment, since there are still school supervisors who have not fully grasped the six aspects of competency. The phenomena that happens when supervisors conduct coaching has not been maximized, which is in violation of Minimum Service Standards. According to Permendiknas No. 15 of 2010, covering Minimum Service Standards for Basic Education, "the supervisor's visit to the education unit is carried out once a month, with each visit lasting 3 hours to carry out supervision and counseling." The function of managerial supervision competence is anticipated to be performed in a plenary way in order to have an influence on the principal's performance.

School supervisors must be able to master the methods, techniques, and principles of supervision, develop supervisory programs, develop work methods, develop school principals in managing educational units, carry out administration, assist school principals in compiling school success indicators, foster school staff in carrying out their main duties, and motivate the career development of school principals, teachers, and other education personnel compiles reports on the results of supervision in their target schools and follows up on improving education quality and subsequent supervision programs, encouraging principals to identify strengths and weaknesses in carrying out their primary responsibilities, explaining and monitoring the implementation of innovations and educational policies in the schools that are supported.

According to Permendikbud Number 6 of 2018, on the appointment of teachers as principals, school principals are instructors who are tasked with leading and managing educational units. School principals are assigned to educational units formed by regional governments, including in special regions, for a term of four years, and supervision can be extended for a maximum of three times for a duration of twelve years depending on the study's findings. Every year, work performance is evaluated with the lowest classification "Good."

If the findings of the Work Performance Assessment do not meet the lowest classification of "Good," the Principal concerned will not be able to serve another term as a principal and will be transferred as a teacher. Every year, the principal conducts a work performance evaluation encompassing the employee's work objectives as well as behavior and attendance carried out by the direct supervisor in line with their authority. It such comprises components of the results of management task implementation, as well as the outcomes of entrepreneurial development the outcomes of the execution of teacher and education personnel supervision, the outcomes of the implementation of sustainable personality development, and other duties outside of the primary task based on the principal's workload The Work Performance Assessment, as it is known, is carried out on the basis of tangible proof of enhancing the quality of eight national education standards.

The school supervisor might support the Head of the Provincial, Regency/City Service, or education providers established by the community in carrying out the Work Achievement evaluation. School supervisors are Civil Servants who are delegated complete tasks, responsibilities, and authority by authorized officials to provide academic and management supervision in educational institutions. The authority of school supervisors in carrying out managerial oversight is linked to components of school management that are the principal's primary duty in boosting the efficiency and effectiveness of the school he leads (Gusmiyati et al, 2021; Yusuf et al, 2021). 
Volume 2 (2) 2021

E-ISSN: 2723-6919 P-ISSN: 2746-0827

Improving school principal competency requires appropriate advice and oversight from school supervisors. School supervisors and principals are vital parts of school organizations, where school work programs can operate successfully and smoothly if they are carried out through cooperative coordination according to their respective major functions. School supervisors conduct guidance and assessment by carrying out supervisory functions, both academic and managerial supervision, with three activities that must be carried out: (1) fostering the development of school quality, principal performance, teacher performance, and the performance of all school staff, (2) evaluating and monitoring the implementation and development of school programs, and (3) evaluating the process and results of school development.

There are now 17 high school education units (SMA Negeri) and 12 private high school education units in Ogan Komering Ulu Regency, South Sumatra Province. Of course, inequalities in academic accomplishment of school inhabitants and total school achievement exist in the course of the existence of existing schools. This is due to a variety of circumstances. There are several phenomena of schools whose performance is poor or slow, as evidenced by the value of school accreditation that does not increase, and in some cases decreases, little or no addition of school infrastructure, and a lack of competitive spirit among principals, educators, and education staff, as well as students, to participate in achievement competitions. Not meeting the "GOOD" benchmark for evaluating school administrators' work performance, among other things, is a common occurrence in the school setting. It is critical to do research on the impact of managerial supervision and work motivation on the performance of high school administrators in Ogan Komering Ulu Regency.

\section{B. Methods}

This study employs a quantitative technique that is descriptive in nature (Sugiyono, 2003). Descriptive research is study that is done to discover the value of independent variables, either one or more (independent) variables, without drawing comparisons or linking with other variables. Because the total population in this study was only 29 and less than 100, the researchers used total sampling to determine the number of samples. Total sampling is a sampling technique in which the number of samples is the same as the population (Sugiyono, 2008). According to Sugiyono (2015), total sampling is employed since the whole population is fewer than 100, and the entire population is used as a study sample. A questionnaire was used as the study tool. The researcher utilized SPSS to do descriptive statistical analysis and inferential statistical analysis on the data acquired from the questionnaire.

\section{Results and Discussion}

\section{The Effect of Managerial Supervision on the Performance of the Principal}

The regression line equation may be represented as $\mathrm{Y}=2,324+0,491 \mathrm{X} 1$ based on the analysis findings. The coefficient of management oversight is 0.491 , according to the equation. This suggests that increasing the managerial oversight variable by one unit will raise the principal's performance by 0.491 units. The regression coefficient $(\mathrm{r}(\mathrm{x}, \mathrm{y}))$ is 0.524 , and the coefficient of determination $(\mathrm{r} 2(\mathrm{x}, \mathrm{y}))$ is 0.275 , based on the findings of the basic regression study above. This means that $27.50 \%$ of the managerial supervision variable may explain the principal's performance variable (Y). Meanwhile, 72.50 percent is explained by factors not considered in this model. The effect of management supervision (X1) on the performance of the principal is 
Volume 2 (2) 2021

E-ISSN: 2723-6919 P-ISSN: 2746-0827

being investigated (Y). The t test can be used to determine the significance of this hypothesis. The independent variable has a substantial influence on the dependent variable if $t$ count is bigger than $\mathrm{t}$ table. The $\mathrm{t}$ distribution table shows that the $\mathrm{t}$ table value $(\mathrm{t}, \mathrm{df}: \mathrm{n}-2)=(\mathrm{t} 0.05,18)$ $=2,100$. The calculation above shows that $\mathrm{t}$ count $>\mathrm{t}$ table $(2.610>2.100)$, implying that managerial supervision has a significant effect on the principal's performance (Kurniadi et al, 2021).

\section{The Effect of Work Motivation on the Performance of the Principal}

The regression line equation may be represented as $Y=2.729+0.392 \mathrm{X} 2$ based on the analysis findings. The coefficient of work motivation is 0.392 , according to the equation. This indicates that if the work motivation variable alone improves by one unit, the principal's performance will increase by 0.392 units. The regression coefficient $(\mathrm{r}(\mathrm{x}, \mathrm{y}))$ is 0.484 , and the coefficient of determination $(\mathrm{r} 2(\mathrm{x}, \mathrm{y}))$ is 0.234 , based on the findings of the basic regression study above. This means that 23.40 percent of the work motivation variable may explain the principal's performance variable (Y). Meanwhile, 72.60 percent is explained by factors not considered in this model. The influence of work motivation (X2) on the principal's performance is being investigated $(\mathrm{Y})$. The $\mathrm{t}$ test can be used to determine the significance of this hypothesis. The independent variable has a substantial influence on the dependent variable if $t$ count is bigger than $\mathrm{t}$ table. The $\mathrm{t}$ table value is $(\mathrm{t}, \mathrm{df}: \mathrm{n}-2)=(\mathrm{t} 0.05,92)=2,100$ based on the $\mathrm{t}$ distribution table. The math above demonstrates that $t$ count $>t$ table $(2,345>2,100)$, implying that work motivation has a considerable impact on the principal's performance (Riyany et al, 2021).

\section{The Effect of Managerial Supervision and Work Motivation on Principal Performance}

The ANOVA test is used to determine the significance of two variables at the same time. The test findings are as follows: The purpose of this test is to assess the importance of the combined impact of management supervision (X1) and work motivation (X2) on the performance of the principal (Y). The $\mathrm{F}$ test can be used to determine whether or not this hypothesis has a substantial effect. If the computed $\mathrm{F}$ exceeds the $\mathrm{F}$ table, the independent factors have a considerable impact on the dependent variable. The $\mathrm{F}$ table value is $(\mathrm{F}, \mathrm{df}: \mathrm{k}, \mathrm{n}-\mathrm{k}-1)=(\mathrm{F} 0.05$, $2.17)=3.59$ based on the $\mathrm{F}$ distribution table. According to the aforementioned computation, F count $>\mathrm{F}$ table $(3.749>3.59)$. This might be construed to mean that management oversight and work motivation have a substantial impact on the principal's performance (Prihatini et al, 2021).

Based on the description of the simple study above, it is possible to conclude that the variables of management oversight and work motivation have a beneficial impact on the principal's performance. Although the coefficients are not significant at the same time, all variables are statistically significant in some way. The two variables' direction and number of coefficients are also consistent. This is a common finding in small-sample observations.

\section{Conclusion}

When the management supervision variable (X1) is analyzed partially using a basic linear regression statistical approach, it can be stated that it is statistically significant and has a favorable influence on employee performance (Y). The coefficient of managerial supervision variable (X1) is bigger than the coefficient of work motivation variable after both the simultaneous ( $\mathrm{F}$ test) and partial ( $\mathrm{t}$ test) (X2). This suggests that the management supervision 
Volume 2 (2) 2021

E-ISSN: 2723-6919 P-ISSN: 2746-0827

variable (X1) has a stronger impact on employee performance than the job motivation variable (X2). Although it makes a smaller contribution, the work motivation variable (X2) has a favorable effect on employee performance (Y). Furthermore, the findings of basic regression analysis reveal that the $\mathrm{t}$ test results are statistically significant. Furthermore, both the management supervision variable (X1) and the employee motivation variable (X2) have a considerable effect on the employee performance variable (Y). Simultaneously, managerial oversight and staff motivation have a favorable and substantial influence on the performance of the principal of SMA Ogan Komering Ulu Regency.

\section{E. Acknowledgement}

We thank to Rector Universitas PGRI Palembang, Dinas Pendidikan Propinsi Sumatera Selatan and friends who have supported us to do this project.

\section{References}

Devi, D., Harapan, E., \& Wardiah, D. (2021). The Implementation of Principal's Supervision in SD Negeri Tungkal Ilir Banyuasin (Teacher's Competency Development Study). Journal of Social Work and Science Education,2(1), 60-68. https://doi.org/10.52690/jswse.v2i1.206

Dirjen Peningkatan Mutu Pendidik Dan Tenaga Kependidikan. (2009). Survei Para Pengawas Tahun 2008 [Supervisory Survey 2008]

Firman, F., Fitria, H., \& Rohana, R. (2021). The Influence of School Leadership Style and Teacher's Motivation toward Teacher's Performance. Journal of Social Work and Science Education, 2(1), 1-10. https://doi.org/10.52690/jswse.v2i1.134

Gusmiyati, G., Lian, B., \& Fitria, H. (2021). Principal's Supervision in Improving Teacher's Performance. Journal of Social Work and Science Education,2(1), 83-94. https://doi.org/10.52690/jswse.v2i1.209

Kurniadi, R., Lian, B., \& Wahidy, A. (2021). Visionary Leadership and Organizational Culture on Teacher's Performance. Journal of Social Work and Science Education, 1(3), 249256. https://doi.org/10.52690/jswse.v1i3.112

Permendikbud Nomor 6 tahun 2018 [Regulation of the Minister of Education and Culture Number 6 of 2018]

Permendiknas Nomor 19 Tahun 2007 [Regulation of the Minister of National Education Number 19 of 2007]

Permendiknas Nomor 13 Tahun 2007 [Regulation of the Minister of National Education Number 13 of 2007]

Permendiknas Nomor 12 Tahun 2007 [Regulation of the Minister of National Education Number 12 of 2007] 
Volume 2 (2) 2021

E-ISSN: 2723-6919 P-ISSN: 2746-0827

Permendiknas No. 15 Tahun 2010 [Regulation of the Minister of National Education Number 15 of 2010]

Peraturan Pemerintah Nomor 19 Tahun 2005 [Government Regulation Number 19 of 2005]

Permenpan RB No. 21 Tahun 2010 [RB Regulation No. 21 Year 2010]

Prihatini, D., Arafat, Y., \& Mulyadi, M. (2021). The Influence of Organizational Culture and Principal Leadership Towards Teacher's Performance. Journal of Social Work and Science Education, 1(3), 204-213. https://doi.org/10.52690/jswse.v1i3.107

Riyany, E., Harapan, E., \& Tahrun, T. (2021). School Principal's Strategy in Developing Teacher's Professional Competencies to Improve Educational Quality. Journal of Social Work and Science Education, 1(3), 214-220. https://doi.org/10.52690/jswse.v1i3.108

Sugiyono. (2003). Metode Penelitian Kuantitatif Kualitatif dan R\&D [Qualitative Quantitative Research Methods and $R \& D$ ]. Bandung: Alfabeta.

Sugiyono. (2008). Metode Penelitian Kuantitatif Kualitatif dan R\&D [Qualitative Quantitative Research Methods and R\&D]. Bandung: Alfabeta

Sugiyono. (2015). Metode Penelitian Pendidikan: Pendekatan Kuantitatif, Kualitatif dan R\&D [Educational Research Methods: Quantitative, Qualitative and R\&D Approach]. Bandung: Alfabeta.

Susilawati, S., Fitria, H., \& Eddy, S. (2021). The Effect of Principal's Leadership Style and Teacher's Job Satisfation towards Teacher's Performance. Journal of Social Work and Science Education, 2(1), 42-51. https://doi.org/10.52690/jswse.v2i1.192

Yusuf, M., Fitria, H., \& Mulyadi, M. (2021). The Influence of Teacher's Supervision and Professionalism on Teacher's Performance. Journal of Social Work and Science Education, 1(3), 234-240. https://doi.org/10.52690/jswse.v1i3.110 